\title{
Chapter 4 \\ Teenage Apprentices at Risk: \\ Corporate Imaginings of Polyharmony \\ (Luxembourg, c. 1910-1940)
}

\section{Introduction: The Exhausted Nation and Imaginings of Polyharmony}

At the beginning of the twentieth century, the mining and steel industries produced enormous amounts of corporate images for internal and external communication. ${ }^{1}$ Since then, much has been written about corporate photography and visual representations of adult, male workers, ${ }^{2}$ but there has been relatively little systematic analysis of corporate photographic collections with a specific focus on youth. ${ }^{3}$ In this chapter, I will analyze corporate images made in the context of the Luxembourg steelmanufacturing conglomerate Aciéries Réunies de Burbach-Eich-Dudelange (ARBED), a

1 Ralf Stremmel, "Mythen schmieden? Fotografien von Jugend in der Montanindustrie, 1949-1973," in Jugend im Fokus von Film und Fotografie, ed. Barbara Stambolis and Markus Köster (Göttingen: V\&R Unipress 2016), 81; Frederik Herman and Karin Priem, "Images of Industrial Life and Vocational Training: Scouting as a Liminal Space for Educating a Workers' Elite in 1920s Luxembourg," History of Education 49, no. 4 (2020): 553-570, DOI:10.1080/0046760X.2019.1701098.

2 Stremmel, "Mythen schmieden?"; Elspeth H. Brown, The Corporate Eye: Photography and the Rationalization of American Commercial Culture (1884-1929) (Baltimore, MD: Johns Hopkins University Press, 2005); Roland Marchand, Creating the Corporate Soul: The Rise of Public Relations and Corporate Imagery in American Big Business (Berkeley: University of California Press, 1999); Klaus Türk, "Arbeit in der bildenden Kunst," in Anthropologie der Arbeit, ed. Ulrich Bröckling and Eva Horn (Tübingen: Gunter Narr Verlag, 2002), 35-77; Klaus Türk, Bilder der Arbeit: Eine ikonografische Anthologie (Wiesbaden: VS Verlag für Sozialwissenschaften, 2000); Ulrich Wengenroth, "Die Fotografie als Quelle der Arbeits- und Technikgeschichte," in Bilder von Krupp: Fotographie und Geschichte im Industriezeitalter, ed. Klaus S. Tenfelde (Munich: C. H. Beck, 2000), 98-104; Manfred Wahle, "Every Picture Tells a Story: Historical Research on Vocational Education and Training," in History of Vocational Education and Training in Europe: Cases, Concepts and Challenges, ed. Ester Berner and Philipp Gonon (Bern: Peter Lang Publishing, 2017), 207-228.

3 Stremmel, "Mythen schmieden," 82. Stremmel explores the historical archive of the German steel factory Krupp.

Note: An adapted German translation of this chapter was published as Frederik Herman, "Das harmonische Leben im industriellen Kosmos: Darstellungen zukünftiger Arbeiter in der ersten Hälfte des 20. Jahrhunderts in Luxemburg," in Pädagogisierung des »guten Lebens «: Bildungshistorische Perspektiven auf Ambitionen und Dynamiken im 20. Jahrhundert, ed. Andrea De Vincenti et al. (Bern: Bibliothek am Guisanplatz, 2020), 325-354. 
major global player in the twentieth century steel and iron business, and Luxembourg's main driver of socio-cultural transformation and economic prosperity. These photographs, generally made at the request of the industrialists, offer a vivid glimpse into the industrial cosmos created at the beginning of the twentieth century by ARBED. ${ }^{4}$ These photographs not only documented various facets of the industry (e.g., steel plants, manufacturing procedures, laboring bodies, and social welfare initiatives set up for the workers), but also actively (re)constructed and shaped this industrial present.

More concretely, this chapter examines the historically and culturally specific (re)mediation of young workers in the context of vocational training in the first half of the twentieth century in Luxembourg - a period of massive social, cultural, and economic transformations triggered by the country's belated but rapid industrialization. By analyzing the visual traces of teenage workers in a huge corporate holding of 2,251 still images, and by situating these images within their larger historical and sociocultural context, this chapter aims at "reconstructing the photographs' connotative codes" 5 and at gaining insight into their recurring visual (and textual) articulations regarding harmony. ${ }^{6}$ In other words, I investigate how these photographs have presented and reinforced various concepts of harmony that had their origins in a variety of fields: from thermodynamics, to naturism, to political ideologies. Indeed, it was believed at the time that society - after being disharmonized by industrialization, mechanization, urbanization, migration, etc. - had to find a new equilibrium in order to guarantee people's physical, mental, and social well-being as well as industrial prosperity and "economic harmony."7 Thus, these pictures testify to contemporaries' attempts to (re-)harmonize body, mind, and machine; the various bodies within the social organism; the past, present, and future; and nature, culture, and industry. Industrial modernity thus triggered the specter of an unstable, sick civilization on the one hand, and imaginations of the ideally educated - that is, harmonious and wellbalanced - modern man and the good/harmonious life on the other. This said, it should not come as a surprise that harmony and associated concepts, such as equilibrium and synchrony, were often used in the context of educationand thus frequently appeared in the publications coming out of a progressive vocational school that is at the core of this chapter: the Institut Emile Metz (IEM). ${ }^{8}$ I argue that these photographs

4 For more information about the holding, see Marguy Consémius, Françoise Poos, and Karin Priem, eds., Forging a Modern Society: Photography and Corporate Communication in the Industrial Age. ARBED 1911-1937 (Dudelange: CNA, 2017).

5 Brown, The Corporate Eye, 15.

6 Geert Thyssen and Frederik Herman, "Re-turning Matters of Body_Mind: Articulations of Ill-/ Health and Energy/Fatigue Gathered through Vocational and Health Education," History of Education 48, no. 4 (2019): 496-515.

7 ARBED, Oeuvres sociales (Luxembourg: Victor Bück, 1922), 42.

8 ARBED, Oeuvres sociales, 41. 
are "visual metaphors" for contemporaries' search for polyharmony and, thus, demonstrate that various concepts of harmony found their way into educational thought and practice. ${ }^{9}$ Of course, defining harmony as an educational goal was far from new; it is the accumulation of various concepts of harmony, or polyharmony, and associated practices that makes for an extremely interesting case study.

I will start this chapter by giving a short description of the IEM's corporate photography holding, followed by an exploration of the ways in which, and to what extent, teenage apprentices are (re)presented in this holding and how they seem to have been exposed to the school's hybrid curriculum, consisting of formal and semiformal learning activities. The next section looks at five images from the corporate holding and analyzes how they visualize and perform contemporary concepts of harmony, ${ }^{10}$ which were considered essential to protect "contemporary youth - above all the unprivileged youth - from Sick Civilization," and to create the ideally educated and harmonious modern worker. ${ }^{11}$ Finally, I will discuss how, in the reasoning of the institute's founders, polyharmony became synonymous with happiness - a stated educational goal of the IEM.

\section{Instrumentalizing Corporate Photography}

From its founding in 1911, ARBED relied on photography and motion pictures to communicate with its clients, attract new workers, document and record its history, and familiarize the population with the "machine age" and the social dimensions of modernity. ${ }^{12}$ The company's eagerness to visually portray its industrial cosmos was inspired by industrialists in neighboring countries (e.g., Krupp in Germany), who

9 Hermine Feinstein, “Meaning and Visual Metaphor," Studies in Art Education 23, no. 2 (1982): 45-55. 10 Elizabeth Edwards, "Entangled Documents: Visualized Histories," in Susan Meiselas: In History, ed. Kristen Lubben (Göttingen: Steidl, 2008), 330-341; Elizabeth Edwards, "Photography and the Material Performance of the Past,” History and Theory 48, no. 4 (2009): 130-150.

11 Kurt Hahn, 1958, quoted in Winfried Böhm, “Über das 'Praktische' am Praktischen Lernen," In Schnee vom vergangenen Jahrhundert: Neue Aspekte der Reformpädagogik, ed. Winfried Böhm et al. (Würzburg: Ergon, 1994), 72, emphasis in the original. Unless otherwise indicated, all translations are the author's.

12 Frederik Herman, Karin Priem, and Geert Thyssen, "Body_Machine? Encounters of the Human and the Mechanical in Education, Industry and Science," History of Education 46, no. 1 (2017): 108-127. See also, Karin Priem and Frederik Herman, eds. Fabricating Modern Societies: Education, Bodies, and Minds in the Age of Steel (Leiden: Brill, 2019); Ira Plein, "Machines, Masses, and Metaphors: The Visual Making of Industrial Work(ers) in Interwar Luxembourg," in Herman and Priem, Fabricating Modern Societies, 35-57; Frederik Herman and Ira Plein, "Envisioning the Industrial Present: Pathways of Cultural Learning in Luxembourg (1880s-1920s),” Paedagogica Historica 53, no. 3 (2017): 268-284; Robert Hariman and John Louis Lucaites, The Public Image: Photography and Civic Spectatorship (Chicago: University of Chicago Press, 2016). 
had started using photography in the late nineteenth century for a variety of purposes, including sales campaigns for the company's products, educational innovation, and scientific achievements in domains such as vocational orientation, employee selection, and fatigue and motion studies. ${ }^{13}$

Photography was a preferred medium to communicate ARBED's objectives since it was seen as documenting the world objectively. Photographic images appeared to be transparent and immediate, and able to offer a fresh and positive perception of the new industrial world - its landscapes, machineries, production processes and lifestyles not least by devising new ways of staging, aestheticizing, presenting, promoting, and normalizing. ${ }^{14}$ Moreover, mechanical reproduction and mass production enabled fast and infinite repetition, dissemination, and circulation of these pictures throughout different media. ${ }^{15}$ The photographs I am dealing with in this chapter appeared and reappeared, for instance, in historical brochures, albums, magazines, promotional materials, as well as the annual reports of the company's vocational school, the Institut Emile Metz (IEM). The permanent remediation of these images demonstrate ARBED's strong belief in new visual technologies as engines of corporate identity formation, societal transformation, and means of mediating modernity. ${ }^{16}$ Therefore, it is no surprise that ARBED's leaders, just like captains of industry in neighboring countries, were soon convinced of the necessity of establishing their own photography department. ${ }^{17}$ The industrialists' attempt to create a positive self-image was a direct response to societal anxieties and reservations about industrial modernity, and teenage apprentices and workers at risk, as well as a visual counter-offensive designed to "light up the darkness" of industrial society. ${ }^{18}$

Most of the images in ARBED's corporate holding of approximately 2,251 glass plate negatives - originally stored at the IEM and now archived at Luxembourg's

13 Stremmel, "Mythen schmieden," 81. See also David E. Nye, Image Worlds: Corporate Identities at General Electric (Cambridge, MA: The MIT Press, 1985); Brown, The Corporate Eye.

14 Plein, "Machines, Masses, and Metaphors," 53; Karin Priem and Frederik Herman, "Introduction," in Priem and Herman, Fabricating Modern Societies, 10.

15 Elizabeth Edwards, "Entangled Documents: Visualized Histories," 330-341; Elizabeth Edwards, "Photography and the Material Performance of the Past," History and Theory 48, no. 4 (2009): 130-150.

16 Jay D. Bolter and Richard Grusin, Remediation: Understanding New Media (Cambridge, MA: MIT Press, 1999).

17 The Krupp company in Essen (Germany) founded a separate department for industrial photography as early as 1861, see Stremmel, "Mythen schmieden," 81 . See also Klaus S. Tenfelde, ed., Bilder von Krupp: Fotographie und Geschichte im Industriezeitalter (Munich: C. H. Beck, 2000); Wahle, "Every Picture Tells a Story," 207-228. The ARBED department existed until 1970.

18 Exemplary, for instance, is the critical photographic work of the teacher and sociologist Lewis W. Hine. See, for instance, Peter Walther, Lewis W. Hine: America at Work (Cologne: Bibliotheca Universalis, 2018). Damarice Amao, Florian Ebner, and Christian Joschke, Photographie, arme de classe: la photographie sociale et documentaire en France, 1928-1936 (Rio de Mouro: Printer Portuguesa, 2018). 
Centre national de l'audiovisuel - depict industrial landscapes and infrastructures, manufacturing procedures and steel products, ARBED workers and engineers, teachers of the IEM, as well as the barons and baronesses of the steel industry. The pictures also documented activities at the IEM itself - the place where the collection was kept until 2007 and after which it is named. ${ }^{19}$ Popular motifs included the institute's modern infrastructure and its laboratory of psychophysiology, as well as the various work pieces made by the pupils. However, young apprentices, as "students" or "future workers," are a rather marginal motif in this collection, even though it originated from a vocational school. ${ }^{20}$ Apprentices are mostly absent from images of the school, and they rarely appear in images of the steel plant's production halls or together with adult workers. Apprentices only appear in fifteen images, shown participating in theoretical instruction, practical training, and psychophysiological testing, as well as sports activities at the institute's gym and playground. In fact, only 156 out of the 2,251 photographs, just over 10 percent, show apprentices: in staged poses or captured accidentally in the foreground or background of the pictures. Most of this sample of 156 photographs, 125 in total, show the apprentices participating in organized leisure activities, such as the IEM's Boy Scouts and the institute's music band (established in 1920). As one of the many social welfare provisions set up and financed by ARBED's captains of industry, the Loups blancs (White Wolves) Boy Scouts troop was founded in May 1915 as a vital part of the IEM. It aimed at further mobilizing the commitment and skills of the best apprentices for future service in the steel plants, more specifically in a leadership function, such as shop leader and foreman. ${ }^{21}$ The Scout

19 For more information on the foundation of the IEM, the founders' motives and the institute's educational program, see also Karin Priem and Geert Thyssen. "Fragmented Utopia: Luxembourgian Industrialists, Intellectual Networks and Social-Educational Reforms between Tradition and Avant-Garde," Jahrbuch für Historische Bildungsforschung 19 (2013): 106-126; Frederik Herman, "Forging Harmony in the Social Organism: Industry and the Power of Psychometric Techniques," History of Education 43, no. 5 (2014): 592-614; Frederik Herman, Karin Priem, and Geert Thyssen, "Body_Machine? Encounters of the Human and the Mechanical in Education, Industry and Science," History of Education 46, no. 1 (2017), 108-127; Frederik Herman and Karin Priem, "The Eye of the Machine: Labor Sciences and the Mechanical Registration of the Human Body," in Priem and Herman, Fabricating Modern Societies, 138-166; Karin Priem and Frederik Herman, "'Sensuous Geographies' in the 'Age of Steel': Educating Future Workers' Bodies in Time and Space (1900-1940),” in Priem and Herman, Fabricating Modern Societies, 111-137; Geert Thyssen and Frederik Herman, "Re-turning Matters of Body_Mind: Articulations of Ill-/Health and Energy/Fatigue Gathered through Vocational and Health Education," 496-515.

20 This seems to be in line with Stremmel's findings about the Krupp holding. According to Stremmel, young workers were photographed rather infrequently in the first half of the twentieth century. It was only in the second half of the twentieth century that the motif of teenage workers started to play a more important role in corporate photography. See Stremmel, "Mythen schmieden," 82.

21 ARBED, Oeuvres sociales, 46. 
troop served as a complementary semi-formal educational component that - just like the IEM's formal curriculum - aimed to create a new "evolved intermediary class" of workers. $^{22}$

In order to form well-educated, well-balanced workers, the IEM, inspired by ideas borrowed from the international Boy Scouts movement, designed a hybrid curriculum that combined formal and semi-formal learning activities. ${ }^{23}$ The formal curriculum consisted of theoretical instruction (academic and professional knowledge), practical training (specific skills, work ethics, and values) that took place in the institute's workshops, and psychophysiological testing and training (professional orientation). These three centres d'action - as they were called at the IEM - were complemented by natural gymnastics and hygiene classes, all of which, individually and in concert, would help apprentices to smoothly adapt to industrial modernity and lead them toward maximum individual happiness, while also helping to solve the social question. ${ }^{24}$ However, all of this was apparently deemed insufficient, judging from the institute's semi-formal curriculum. Indeed, the institute also organized scouting activities to foster balance and stability, and to form the ideally educated worker. Scouting was understood, in a Rousseauian sense, as the ideal space for "natural learning" (as opposed to artificial learning, which took place in schools). Whether in the city, the forest or at the beach, apprentices could directly experience the world and learn from their own actions - liberated from the prefabricated formal curriculum, and partly freed from supervising and governing authorities. ${ }^{25}$ It was a kind of "liminal space," 26 set apart from the structured spheres of work and formal learning, where one could experiment with new forms of seeing and acting; moreover, it was a "space of regeneration" that would counterbalance the negative by-products of industrialization. ${ }^{27}$ Indeed, modernity was perceived as an era that undermined traditional social and cultural practices and habits, destabilized the collective consciousness, and destroyed old frames of reference. Terrifying images of mankind dominated by the machine, of workers exhausted and diseased by the mechanical or "unnatural" rhythm of the machine and unhealthy working conditions, of mankind deprived of mental and physical freedom as a result of the rational organization of labor, or of dehumanized - passive, amoral, and asocial -

22 Herman, "Forging Harmony in the Social Organism," 611.

23 Herman and Priem, "The Eye of the Machine," 138-166.

24 ARBED, Oeuvres sociales, 42-47.

25 The Scouts' organization should be understood as a "delicate interweaving of adult- and peercontrol, and autonomy and freedom"; see Reuven Kahane, The Origins of Postmodern Youth: Informal Youth Movements in a Comparative Perspective (Berlin: De Gruyter, 1997), 55-58. See also Stanley E. Ballinger, "The Natural Man - Rousseau," in Nash, Kamazakias, and Perkinson, The Educated Man, 225-246.

26 Victor Turner, "Liminalität und Communitas," in Ritualtheorien: Ein einführendes Handbuch, ed. Andréa Belliger and David J. Krieger (Opladen: Westdeutscher Verlag, 1998), 251-264.

27 David M. Pomfret, Young People and the European City: Age Relations in Nottingham and SaintEtienne, 1890-1940 (Aldershot: Ashgate, 2004), 103. 
industrial men had to be countered by group activities in the open air and in nature. ${ }^{28}$ This semi-formal curriculum (as well as its depiction) was the answer to workers' organizations and Catholic circles who warned that heavy industry threatened the moral and physical development of young people, and their integration into society.

\section{Visual "Performances" of (Poly-)Harmony}

In the following section, I explore the "connotative codes" of five photographs - depicting teenage apprentices within the IEM's formal and semi-formal educational settings and, while doing so, investigate recurring visual articulations regarding harmony. ${ }^{29}$ In line with the approach developed by Elizabeth Edwards in visual studies in anthropology, I go beyond a narrow "forensic and semiotic analysis of content," which focuses solely on the surface "representations" of images, and approach these images as entangled and interacting with other contemporary textual and visual materials - e.g., IEM annual reports and commemorative books. ${ }^{30}$ Thus, rather than being passive and isolated carriers of meaning, these photographs performed, (re-)enacted, and (re-)constructed meanings within a larger complex of materials. ${ }^{31}$

\section{Mind-Body Harmony}

The first photograph (Fig. 4.1), taken on the institute's playground, is one of the many images that show the apprentices performing rational physical exercises in order to remediate physical deformations, improve their physical constitution, and enhance the intimate and smooth interaction of body and mind. ${ }^{32}$ The staged synchronicity suggests a well-trained, harmonious intra and inter-bodily interaction between the senses, the nervous and muscular system, and the mind. ${ }^{33}$ The ancient slogan mens sana in corpore sano was - according to the institute's gym teacher and

28 Pia Schmid, "Die bürgerliche Kindheit, " in Kindheiten in der Moderne: Eine Geschichte der Sorge, ed. Meike Baader et al. (Frankfurt: Campus Verlag, 2014), 57.

29 Brown, The Corporate Eye, 15.

30 Edwards, "Photography and the Material Performance of the Past," 130.

31 Elizabeth Edwards, "Objects of Affect: Photography beyond the Image," Annual Review of Anthropology 41 (2012): 221-234.

32 Jean-Pierre Thommes, "Die soziale Bedeutung der physischen Erziehung," in L'Institut Emile Metz 1914-1954, ed. Institut Emile Metz (Luxembourg: Imprimerie Bourg-Bourger, 1954), 128.

33 Timo Luks, "Kanalisierte Dynamik, angeordnete Körper: Bewegungsmetaphern, Gesellschaftsordnung und der Industriebetrieb (1920-1960)," in Kontrollierte Arbeit - Disziplinierte Körper? Zur Sozialund Kulturgeschichte der Industriearbeit im 19. und 20. Jahrhundert, ed. Lars Bluma et al. (Bielefeld: Transcript, 2012), 251-281; Karsten Uhl and Lars Bluma, “Arbeit - Körper - Rationalisierung: Neue Perspektiven auf den historischen Wandel industrieller Arbeitsplätze,” in Kontrollierte Arbeit - 


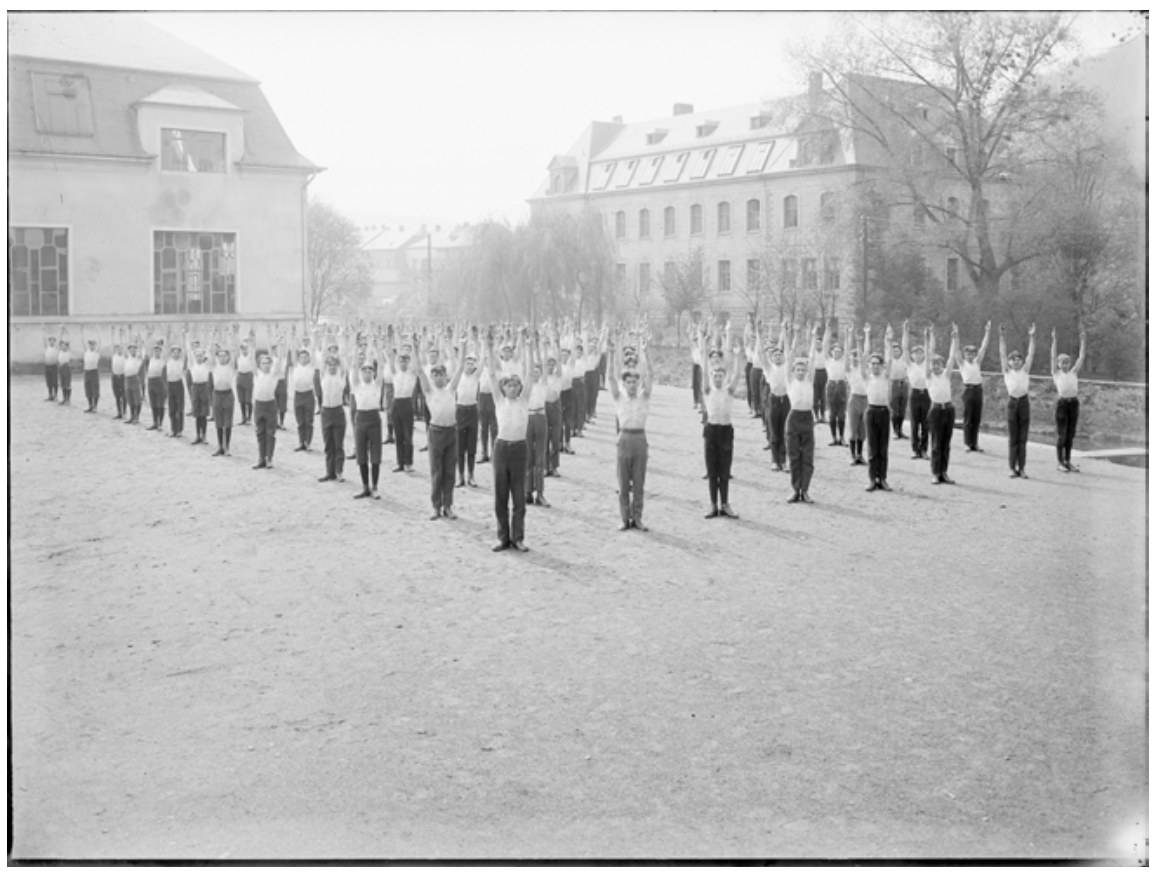

Fig. 4.1: Gymnastics on the institute's playground, n.d. (C) IEM/Inventory no. HISACS002202V01, CNA.

scout leader J. P. Thommes - the institute's credo. ${ }^{34}$ Indeed, such ideas about mindbody harmony and the positive impact of physical training on intellectual abilities were further amplified at the time by newly emerging scientific disciplines such as psychotechnics. $^{35}$ Fritz Giese's publication Körperseele (Bodysoul) from the 1920s illustrates this. ${ }^{36}$ Moreover, Swedish gymnastics and other sports activities, such as swimming, were understood as "stimuli for 'relaxing' movement" 37 and thought to produce "regeneration," compensate for the "assaults of modern life,"38 and

Disziplinierte Körper? Zur Sozial- und Kulturgeschichte der Industriearbeit im 19. und 20. Jahrhundert, ed. Lars Bluma et al. (Bielefeld: Transcript, 2012), 9-31.

34 Thommes, "Die soziale Bedeutung der physischen Erziehung," 128.

35 See also Herman, Priem, and Thyssen, “Body_Machine?”; Priem and Herman, “'Sensuous Geographies' in the 'Age of Steel'”; Herman and Priem, "The Eye of the Machine."

36 Fritz Giese, Körperseele: Gedanken über persönliche Gestaltung (Munich: Delphin-Verlag, 1927).

37 Böhm, "Über das 'Praktische' am Praktischen Lernen," 74.

38 Joan Tumblety, Remaking the Male Body: Masculinity and the Uses of Physical Culture in Interwar and Vichy France (Oxford: Oxford University Press, 2012), 6-8. 
strengthen both "constitution" 39 and "morality." 40 "Vigor of character" and "balance of mind" 41 - that is, "moral hardening" as much as "physical hardening" 42 indeed provided another rationale for practicing gymnastics, to which the IEM attached extraordinary importance. ${ }^{43}$ Physical and moral hardening would prevent the apprentices from falling victim to alcoholism, tuberculosis, and syphilis - social scourges that consumed the "human engine's energy." 44 This focus on energy balance, in fact, brings us to the next concept, namely the harmonious functioning of the "body-motor," at the time a popular metaphor for the human metabolism.

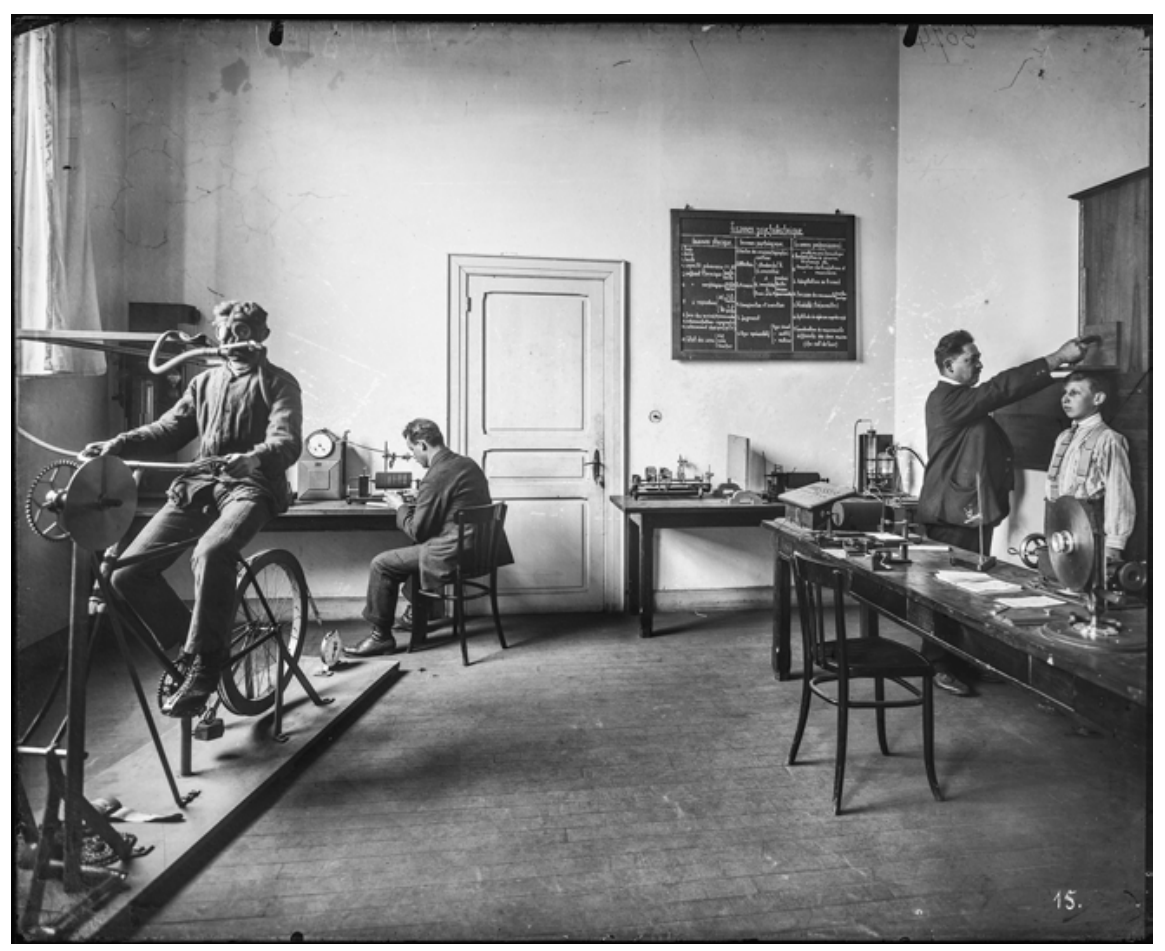

Fig. 4.2: Laboratory of psychophysiology, n.d. (C) IEM/Inventory no. HISACS000714V01, CNA.

39 IEM, Programme publié à la clôture de l'année scolaire 1916-1917/Programm herausgegeben am Schlusse des Schuljahres 1916-1917 (Luxembourg: Victor Bück, 1917), 88.

40 Thommes, "Die soziale Bedeutung der physischen Erziehung," 129.

41 ARBED, Oeuvres sociales, 50.

42 Thommes, “Die soziale Bedeutung der physischen Erziehung,” 128.

43 Herman, Priem, and Thyssen, “Body_Machine?,” 125.

44 Jules Amar, Le moteur humain et les bases scientifiques du travail professionnel (Paris: Dunod et Pinat, 1914). 


\section{The Harmonious Functioning of the Body-Motor}

Fig. 4.2 displays a young worker training on an ergometric cycle in the institute's psychophysiological laboratory, founded in 1919. The laboratory devices, and the applied rational and scientific methods, took their cues from the French industrial ergonomist and fatigue expert Jules Amar (1879-1935). ${ }^{45}$ Amar's career was dedicated to uncover the scientific foundations of human labor and establish theories on energy and fatigue. ${ }^{46}$ The ergometric cycle, as well as the many other devices he developed, ${ }^{47}$ were used to study the architecture and mechanics of the human body, the functioning of human metabolism (e.g., nutrition and oxygen intake, exposure to sunlight) in the context of work, and the muscular motor's energy expenditure and degree of fatigue. ${ }^{48}$ Far from being a new theme, the human energy question was revitalized by the harnessing of electricity for domestic and industrial use, especially in the form of engines, as well as by the newly-emerging sciences, such as psychophysiology, which often compared and linked the human organism to the laws of "general mechanics" and "modern physiology." 49 Amar's key work, Le moteur humain (The human motor) as well as the following quote from his Le rendement de la machine humaine (1909) are good examples of this contemporary preoccupation:

The human machine, for sure the oldest one, is comparable to a normal machine when it comes to measuring its effects. The work it [the body] can perform, and the heat thereby produced have even strengthened the first thermodynamicists in their conviction [that the body is

45 Jules Amar and Paul Painlevé, La prothèse et le travail de mutilés: Conférence faite pour les Oeuvres de Mutilés (Paris: Dunod et Pinat, 1916), 4.

46 Jules Amar, Le moteur humain et les bases scientifiques du travail professionnel (Paris: Dunod et Pinat, 1914); Jules Amar, The Human Motor, or the Scientific Foundations of Labour and Industry (London: George Routledge \& Sons, 1920).

47 For a description of some of his specialized and advanced ergographic and dynamographic apparatuses, see Jules Amar, The Physiology of Industrial Organisation and the Re-employment of the Disabled (London: The Library Press Limited, 1918); Michaela Vieser, Das Zeitalter der Maschinen: Von der Industrialisierung des Lebens (Berlin: Braus, 2014); Käte Meyer-Drawe, Menschen im Spiegel ihrer Maschinen (Munich: Fink, 1996).

48 Anson Rabinbach, The Human Motor: Energy, Fatigue and the Origins of Modernity (Berkeley: University of California Press, 1992), 187. For a brief overview of the history of the experimental method, its devices, and key figures, see Alexandre Klein, "'Lire le corps pour percer l'âme': Outils et appareils à l'aube de la psychologie scientifique à Nancy," in Corps et Machines à l'âge industriel, ed. Laurence Guignard, Pascal Raggi, and Etienne Thévenin (Rennes: Presses Universitaires de Rennes, 2011), 52-54.

49 Aloyse Robert, "La méthode psycho-physiologique du travail et l'orientation professionnelle," in Institut Emile Metz Dommeldange: Programm herausgegeben am Schlusse des Schuljahres 1919-1920, ed. IEM (Luxembourg: Imprimerie Joseph Beffort, 1920), 53-71; Aloyse Robert, "L'apprentissage industriel et l'enseignement professionnel," in Institut Emile Metz Dommeldange: Programm herausgegeben am Schlusse des Schuljahres 1918-1919, ed. IEM (Luxembourg: Imprimerie Universelle Linden \& Hansen, 1919), 47-55. 
a machine]. . . . In reality, it [the body] is composed of many small engines, all of which function harmoniously. ${ }^{50}$

Gaining insight into and training towards the optimal use of human energy - without exhausting the mind or the body and with no loss in productivity - were key at a time when the industry's blunt quest for maximum productivity raised fears of wasting or weakening national human resources. Therefore, a healthy and harmonious functioning of the body-motor had to be studied, trained, and supported by appropriate working and living conditions. It was believed that once these conditions were fulfilled, the human motor would function harmoniously and endlessly, maximizing human energy efficiency. ${ }^{51}$

\section{Harmony between Body, Mind, and Machine}

Closely related to the human energy question - and originating from the same disciplines and experimental settings - were contemporary ideas on achieving symbiosis between the mechanical and natural body, on harmonizing and synchronizing bodies and machines, and on aligning mechanical and natural/human rhythms. ${ }^{52}$ Contemporary discussions on the "fusion" of man and machine, and the maximization of their joint performance, can be characterized by two opposed, yet related, approaches: adapting humans to the machine, and adjusting the machine and the work environment to human abilities. In both cases, it was believed that labor sciences would solve the issue by providing science-based descriptions of how the labor environment could be best adapted to human abilities; by specifying detailed, sciencebased instructions for body posture and the appropriate use of physical strength while performing industrial labor; and by providing testing and training devices that would allow workers to gain insight into their own body-mind as well as body/ mind-machine/tool coordination, rhythm, and energy expenditure. The CNA collection contains a few staged images of human-machine symbiosis. Exemplary images show apprentices performing tests and/or training (e.g., filing and hammering) with a variety of ergometric and dynamographic devices in the IEM's laboratory (Fig. 4.2). These devices - connected to a cylindrical recorder - registered the time it took to perform the test, the punching rhythm, the power used, and the level of fatigue experienced by the test subject. These pictures thus seem to present the harmonious fusion of

\footnotetext{
50 Jules Amar, Le rendement de la machine humaine: Recherches sur le travail (Paris: Baillière, 1909), 10.

51 For more information, see also Herman, Priem and Thyssen, “Body_Machine?”; Herman and Priem, "The Eye of the Machine”; Priem and Herman, “Sensuous Geographies' in the 'Age of Steel.”,

52 Priem and Herman, “'Sensuous Geographies’ in the ‘Age of Steel.”,
} 
body and machine, both completing and perfecting each other in a human-mechanical constellation. Moreover, it was believed that a rational, moderate rhythmic performance, and the harmonious functioning of the body-mind machine, would result in the "polyrhythmical liberation of the body and the spirit" 53 and generate positive emotions, pleasure, and satisfaction. ${ }^{54}$

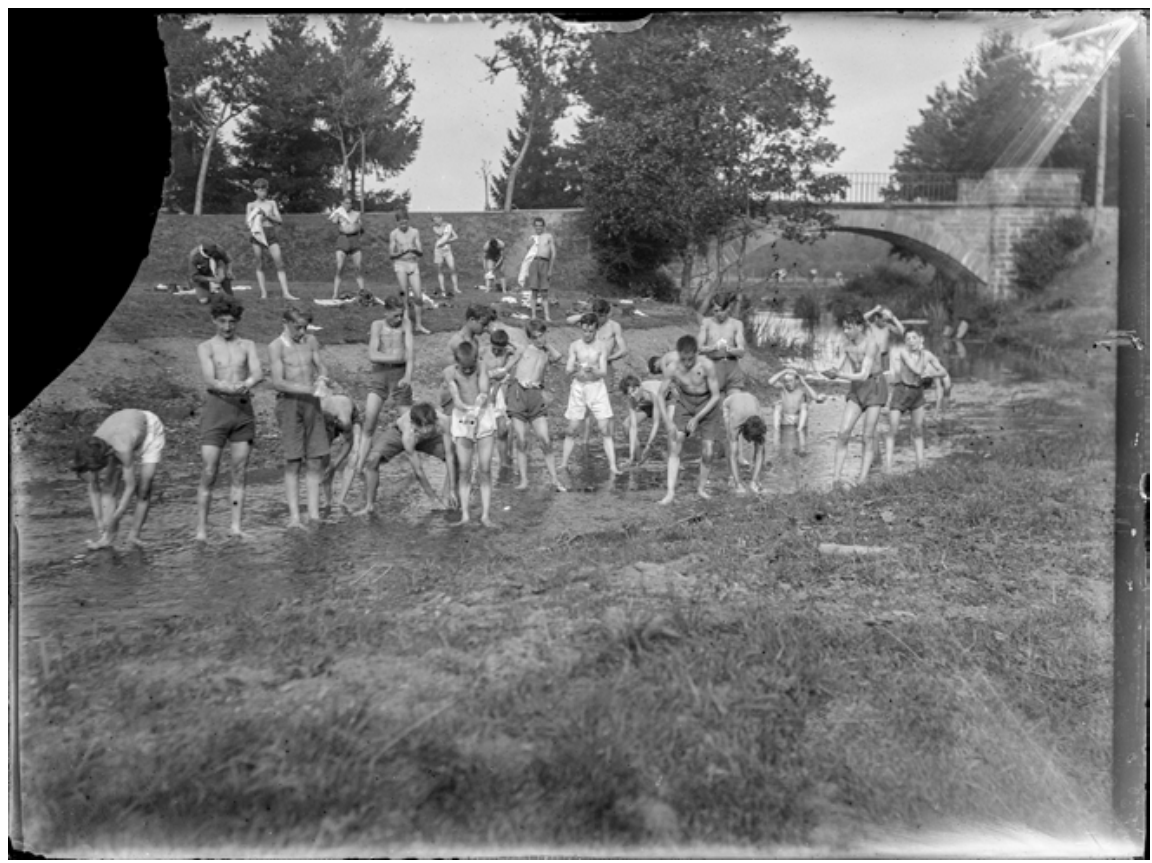

Fig. 4.3: Bathing in the river, Grevenmacher, 1921. (C) IEM/Inventory no. HISACS000299V01, CNA.

\section{In Harmony with Nature and Culture}

The following photographs, taken in the context of the IEM's Boy Scout activities, depict elements of the institute's semi-formal curriculum. To a certain degree, they seem to be counter-images to the first two pictures that mainly echoed an industrial and mechanical rationale. ${ }^{55}$ Several of these photographs show semi-nude bodies

53 Böhm, “Über das 'Praktische' am Praktischen Lernen,” 76.

54 Richard Sennett, The Craftsman (London: Allen Lane, 2008), 235; Mark Paterson, The Senses of Touch: Haptics, Affects and Technologies (Chichester: John Wiley \& Sons, 2012), 30-32.

55 My earlier research focused on images that display these spaces and practices of formal learning, which prepared future workers for mechanical modernity; see, e.g., Herman, "Forging Harmony in the Social Organism,” 592-614; Herman, Priem, and Thyssen, “Body_Machine?,” 108-127; 
exposed to fresh air, sun, and water (heliotherapy, hydrotherapy), and/or engaged in gymnastics and sports activities. This semi-nudity seems to have fitted in with a broader psycho-physical culture that aimed at preventing physical and mental decline. Stripped from "dirty" clothes that could contain the germs of contamination (e.g., tuberculosis), block the sunlight, and obstruct the human motor's ability to move, young bodies were also stripped from visible markers of social inequality and exposed to the hygienist's (pseudo-)scientific gaze. ${ }^{56}$ Cleanliness, purity, revitalization, and preservation as key elements of the new cult of hygiene further justified scrutinizing both the condition and constitution of the young human machine. ${ }^{57}$ Fig. 4.3 shows a bathing scene in a river, in front of a neatly engineered road and bridge that actually contradicts the pure Rousseauian naturalness the image may have wanted to convey. ${ }^{58}$ Besides the displayed activity of bathing, the environment where this activity takes place is also a key element in this presentation. Indeed, many pictures display the Boy Scouts in (semi-)natural environments, thus hinting at Romantic, idyllic aspirations to get in touch with nature in the midst of advancing urbanization and industrial mechanization. Indeed, the shift to nature, outdoor spaces, and open-air activities gained momentum at the time, as can be seen by the Lebensreform and Freikörperkultur movements in Germany, the popularity of naturisme in France, and youth movements like the German Wandervogel and American Scouts. ${ }^{59}$ Nature was seen as the very opposite of industry and the city (healthy vs. dirty, silent vs. noisy, slow vs. speedy) and, thus, as the cure to societal and industrial ills such as physical and mental fatigue. Living temporarily in harmony with nature would allow the teenage worker to refuel and to (re-)generate balance and sanity.

However, the IEM images not only depicted the harmonious connection with nature. The collection also contains several images taken in urban spaces that show the apprentices experiencing modern lifestyles. ${ }^{60}$ The latter seems to be in line with the emerging international understanding of cities as significant learning spaces, where

Herman and Plein, "Envisioning the Industrial Present," 268-84; Herman and Priem, "The Eye of the Machine," 138-166; Priem and Herman, “'Sensuous Geographies' in the 'Age of Steel," 111-137. 56 Thyssen and Herman, "Re-turning Matters of Body_Mind," 496-515.

57 IEM, Stenographischer Bericht der Versammlung vom Dienstag den 17. Juni 1913 (Dommeldingen: Buchdruckerei Albert Nicolay, 1913), 5.

58 Geert Thyssen and Klaus Dittrich, "Water and Dust: Recovering Washed-Out Pasts of Industry in Luxembourg," in Education across Europe: A Visual Conversation, ed. Catherine Burke et al. (n.p.: Network 17, Histories of Education, EERA, 2014), 65.

59 Thyssen and Herman, "Re-turning Matters of Body_Mind," 496-515.

60 For more information, see Herman and Priem, "Images of Industrial Life and Vocational Training." 
one could directly experience urban modernity and modern culture. ${ }^{61}$ These pictures seem to suggest that the ideal modern young worker was not only a skilled laborer, but also a man capable of combining both nature and (industrial and urban) culture and, thus, of achieving harmony and cultural identity.

\section{Harmony between Past and Present}

Fig. 4.4 - presumably showing scouts making hay bales and gathering them onto the hay wagon - can be seen as a response to societal feelings of unease about modernity and to anxieties about losing connection with the country's rural past and traditions. Indeed, many of the IEM images show how apprentices are introduced to the country's cultural heritage, its rural past, historical monuments, and touristic highlights (e.g., ruins of a castle or a bunker at the Belgium coast) or old-style handicrafts such as woodworking and farming. ${ }^{62}$ The displayed "artisanal activity" could be said to connect to the "late-Romantic flight from a reality of life defined by the loss of object and orientation, stress, pressure to perform and competition," and to hint at the "polyrhythmic liberation of the body as it re-remembers the agricultural laborers' earthy, grounded steps" and natural rhythm. ${ }^{63}$ Indeed, pictures of making hay bales in the open air and harvesting in summertime (following the rhythm of the seasons) strongly contrast with images displaying the automated steel production process. As mentioned earlier, the desire to get acquainted with the country's past went hand in hand with the desire to become familiar with the industrial and urban present, and to get to know new, modern lifestyles. It is, therefore, no surprise that the collection also contains several images that romanticized and glorified the industrial and urban present. The juxtaposition of cultural heritage with the urban and industrial present - the equilibration of the old and the new - can be understood as an attempt to reconcile conflicting traditionalist and modernist narratives. Transcending the apprentices' narrow initiation into an industrial trade or craft, these depictions thus aimed at creating “cultured men" - aware of the country's tangible and intangible cultural heritage and present, as well as the fact that man and society are the products of both. ${ }^{64}$ The institute's curriculum thus purposely tried to harmonize past and

61 Håkan Forsell, "Die großstädtische Kindheit," in Kindheiten in der Moderne: Eine Geschichte der Sorge, ed. Meike Sophia Baader, Florian Eßer, and Wolfgang Schröer (Frankfurt: Campus Verlag, 2014), 191-225.

62 See also, Herman and Priem, "Images of Industrial Life and Vocational Training”; Herman and Plein, "Envisioning the Industrial Present."

63 Böhm, "Über das 'Praktische’ am Praktischen Lernen,” 76.

64 G. H. Bantock, "The Cultured Man - Eliot,” in Nash, Kazamias, and Perkinson, The Educated Man, 337-360. 
present, and allowed the young workers to "make meaningful and affectively charged connections across time." 65

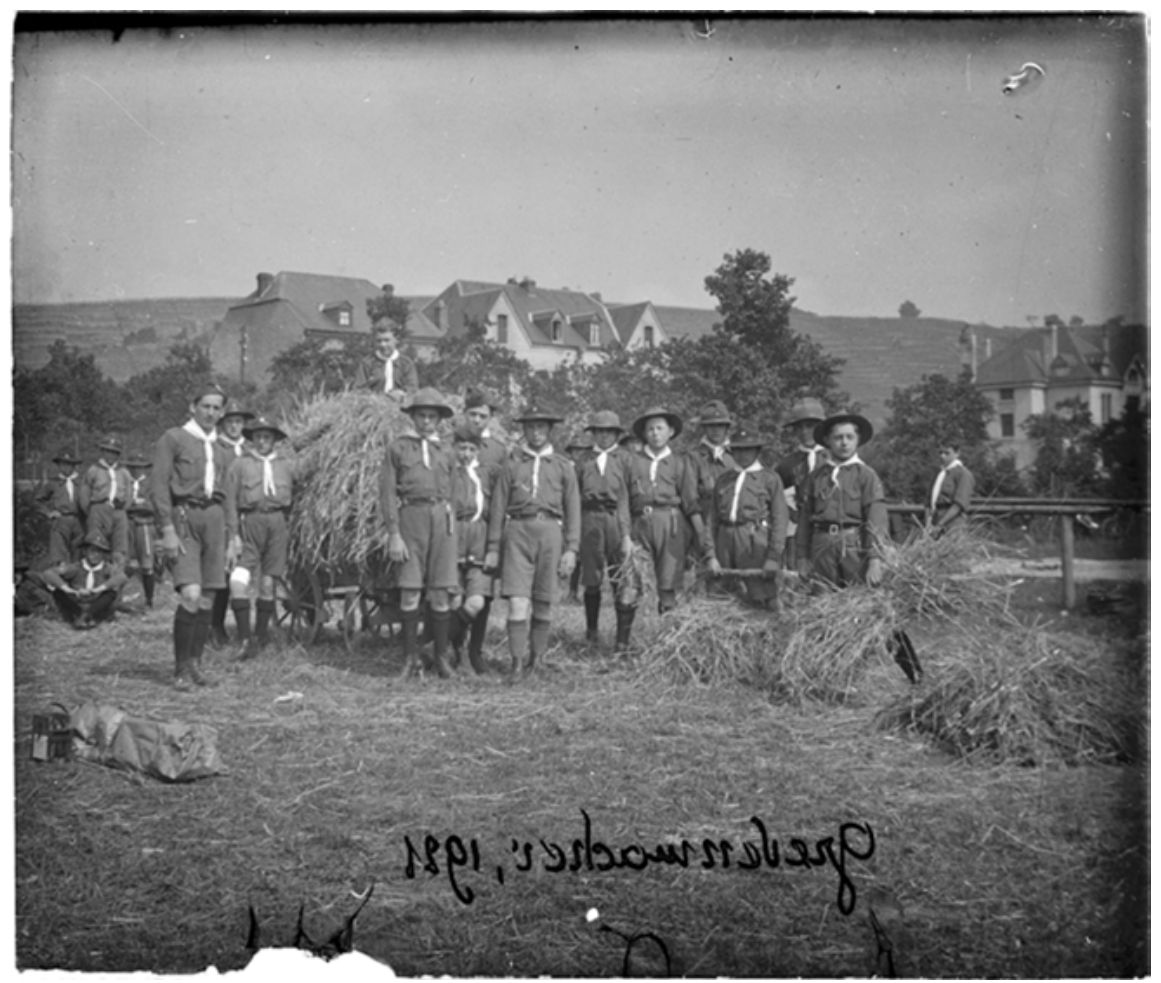

Fig. 4.4: Group picture, Grevenmacher, 1921. @ IEM/Inventory no. HISACS000300V01, CNA.

\section{Harmony within Society}

The last image (Fig. 4.5) displays power and synchronized gymnastics on the beach of Bredene, Belgium, and it is one of the many pictures that display group activities: from peeling potatoes and cooking, to logging wood, to performing various competitive physical exercises. Such activities have been a reaction to the fears of alienation and dehumanization in capitalist technological-industrial society. Indeed, in certain circles it was believed that "[m]odern industrial society has left no other bound between man and man than naked self-interest," or that man in the industrial age "is not his true self because he is alienated; alienated from his work, from other men,

65 Sharon MacDonald, Memorylands: Heritage and Identity in Europe Today (Abingdon: Routledge, 2013), 234. 


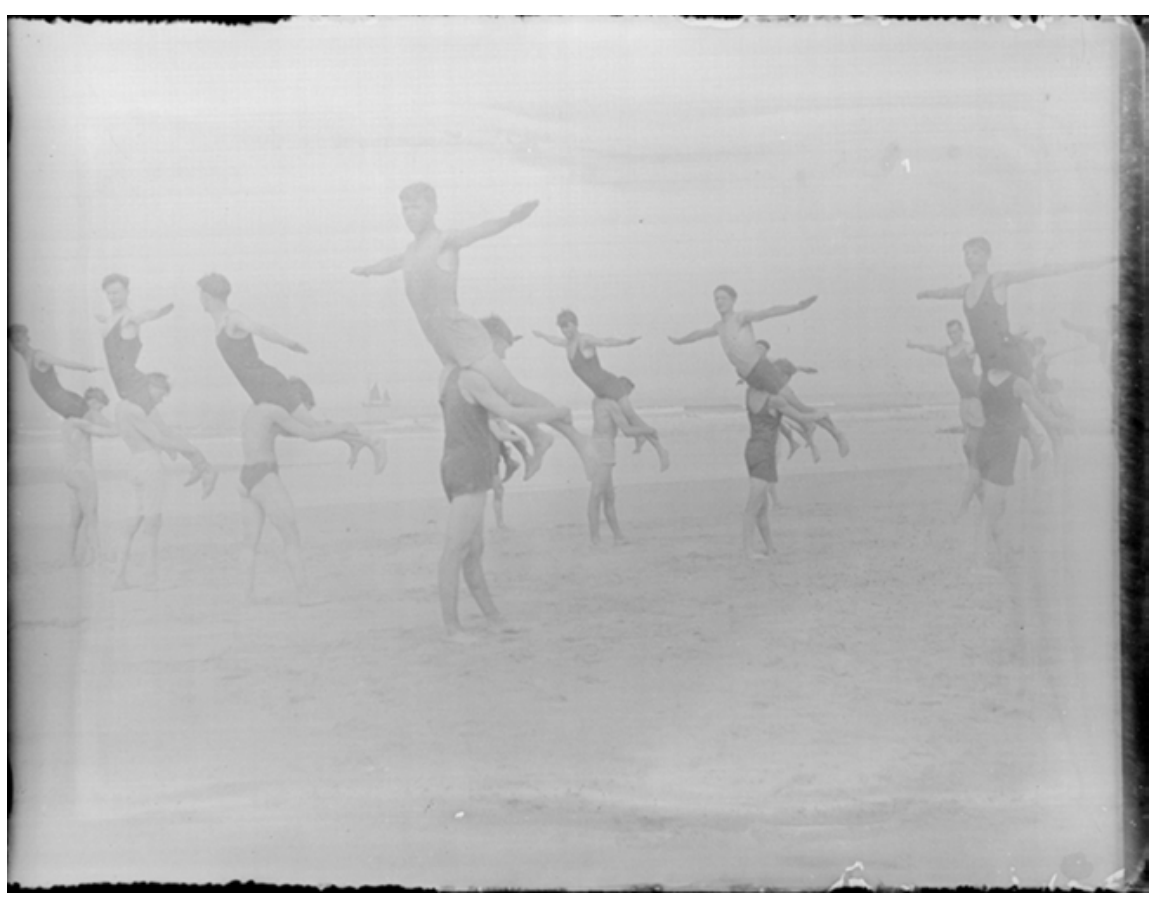

Fig. 4.5: Gymnastics on the beach, Bredene, Belgium, 1926. (C) IEM/Inventory no. HISACS000221V01, CNA.

and from himself." ${ }^{\prime 6}$ The decline of social cohesion and the reduction of the worker to a commodity would result in a "society that loses all sense of morality, fair play and justice." ${ }^{67}$ Images such as the one above were designed to counter these anxieties, by staging various moments of playing and working together. The creation of a strong group feeling was thought to be favorable (and profitable) in the context of labor and society at large. ${ }^{68}$ Collectivity, as well as the importance of the individual within the collective, are key motifs in these photographs. Indeed, the images simultaneously display apprentices as individuals taking up various tasks and/or various positions in the group, as well as the collective success that is possible only if each of them takes his [sic!] proper place, functions optimally, and performs maximally in a

66 Paul Nyberg, “The Communal Man - Marx,” In Nash, Kazamias, and Perkinson, The Educated Man, 277-278.

67 Nyberg, “The Communal Man - Marx,” 278.

68 Thommes, “Die soziale Bedeutung der physischen Erziehung,” 128. 
mutually trusting and cooperative relationship. ${ }^{69}$ Fig. 4.5 could be said to symbolize the desired social cohesion (e.g., the closeness of the apprentices' bodies), social unity, stability or equilibrium, harmony and synchrony at the time of awakening social unrest in Luxembourg. The Scout group and the institute's sport activities served as pre-eminent vehicles for character-building and as a space to experiment with social skills (e.g., camaraderie, cooperativeness, fair play) that were thought to be crucial for the formation of useful and responsible members of human society. ${ }^{70}$

\section{Conclusion: Polyharmony and the Making of Happiness}

The IEM's programmatic hybridity seems to have been a direct response from the captains of industry to the growing critique of education, especially within progressive education circles, which chimed with a more general "'uneasiness in civilization' or, more concretely, with the critique of the living conditions in an evolved industrial society and technological civilization that were deemed inhumane." ${ }^{\text {71 }}$ Indeed, the institute's curriculum was understood by its founders as a means to counteract the "lack of vital cells of the social organism that prefigured an era of transition, a period of moral and political anarchy,"72 and catalyze and ensure sociocultural stability - the fertile ground for a profitable "cult of economic harmony." "73 This chapter has tried to demonstrate how various concepts of harmony - originating from societal fears, economic and political aspirations, ideologies, and the sciences - found their way into educational thought and practice. It has shown how these visual (and textual) materials performed and enacted various forms of harmony, be it the harmony between body, mind, and machine; the smooth and harmonious running of the body-motor; the ability to move flexibly and harmoniously between industrial, urban, and natural environments, and to have a foothold in both the past and the present; and the harmonious social organism. These corporate images, thus, seem to have functioned as "visual metaphors" for the vocational school's (and, by extension, society's) search for polyharmony - a polyharmony that presented an antidote to the disharmony and imbalance that was feared to come with industrial modernity. It would seem that

\footnotetext{
69 Herman, "Forging Harmony in the Social Organism"; Herman and Priem, "Images of Industrial Life and Vocational Training”; Herman and Plein, "Envisioning the Industrial Present."

70 Thommes, “Die soziale Bedeutung der physischen Erziehung,” 128, 130.

71 Waltraud Harth-Peter, "Schnee vom vergangenen Jahrhundert? Zur Aktualität der Reformpädagogik heute," in Schnee vom vergangenen Jahrhundert: Neue Aspekte der Reformpädagogik, ed. Winfried Böhm et al. (Würzburg: Ergon, 1994), 12.

72 ARBED, Oeuvres sociales, 41.

73 ARBED, Oeuvres sociales, 42.
} 
harmony, rhythm, and equilibrium were the key messages that industrialists wished to convey, through the institute's curriculum and these corporate images, to the lower classes who suffered most in times of rapid industrialization. According to the institute's founders, a poly-harmonious state of being would result in lasting happiness and maximum productivity. ${ }^{74}$

Acknowledgments: This article brings together the different research lines and topics that I was able to explore together with Prof. Dr. Karin Priem (PI) and Dr. Geert Thyssen while working on the FAMOSO project at the University of Luxembourg from 2013 until 2018. It combines the thoughts of various FAMOSO research papers listed in the bibliography. For the sake of concision, some references to these (co-)authored works have been omitted in agreement with my co-authors. I also would like to express my gratitude to my former FAMOSO colleagues (Dr. Klaus Dittrich, Dr. Irma Hadzalic, Prof. Dr. Enric Novella, Dr. Ira Plein, Dr. Françoise Poos) and advisers for their support and input. Likewise, I want to thank the organizers (Prof. Dr. Francisca Comas Rubí) and participants of the symposium workshop "Photography and Educational Practice” (University of the Balearic Islands, April 4-5, 2019), as well as the organizers (Dr. Lukas Boser, Dr. Andrea De Vincenti, Prof. Dr. Norbert Grube, Dr. Michèle Hofmann, Philippe Müller) and participants of the conference "Pädagogisierung des 'guten Lebens"” (Bern, 2018) for having inspired this article. I am also obliged to the staffs of the Centre national de l'audiovisuel, the Bibliothèque nationale de Luxembourg (BnL), and the Archives nationales de Luxembourg. Finally, I am greatly indebted to Manuela Thurner for her critical reading and editorial revisions of this essay.

\section{Bibliography}

Amao, Damarice, Florian Ebner, and Christian Joschke. Photographie, arme de classe: la photographie sociale et documentaire en France, 1928-1936. Rio de Mouro: Printer Portuguesa, 2018.

Amar, Jules. Le moteur humain et les bases scientifiques du travail professionnel. Paris: Dunod et Pinat, 1914.

Amar, Jules. Le rendement de la machine humaine: Recherches sur le travail. Paris: Baillière, 1909.

Amar, Jules. The Human Motor, or the Scientific Foundations of Labour and Industry. London: George Routledge \& Sons, 1920.

Amar, Jules. The Physiology of Industrial Organisation and the Re-employment of the Disabled. London: The Library Press Limited, 1918.

Amar, Jules, and Paul Painlevé. La prothèse et le travail de mutilés: Conférence faite pour les Oeuvres de Mutilés. Paris: Dunod et Pinat, 1916.

ARBED. Oeuvres sociales. Luxembourg: Victor Bück, 1922.

74 ARBED, Oeuvres sociales, 29. 
Ballinger, Stanley E. "The Natural Man - Rousseau." In The Educated Man, edited by Andreas M. Kazamias, and Henry J. Perkinson, 225-246. New York: John Wiley and Sons, 1965.

Bantock, G. H. "The Cultured Man - Eliot." In The Educated Man, edited by Andreas M. Kazamias, and Henry J. Perkinson, 337-360. New York: John Wiley and Sons, 1965.

Böhm, Winfried. “Über das 'Praktische' am Praktischen Lernen.” In Schnee vom vergangenen Jahrhundert: Neue Aspekte der Reformpädagogik, edited by Winfried Böhm, Waltraud HarthPeter, Karel Rýdl, Gabriele Weigand, and Michael Winkler, 51-69. Würzburg: Ergon, 1994.

Bolter, Jay D., and Richard Grusin. Remediation: Understanding New Media. Cambridge, MA: MIT Press, 1999.

Brown, Elspeth H. The Corporate Eye: Photography and the Rationalization of American Commercial Culture (1884-1929). Baltimore, MD: Johns Hopkins University Press, 2005.

Consémius, Marguy, Françoise Poos, and Karin Priem, eds. Forging a Modern Society: Photography and Corporate Communication in the Industrial Age. ARBED 1911-1937. Dudelange: CNA, 2017.

Edwards, Elizabeth. "Entangled Documents: Visualized Histories." In Susan Meiselas: In History, edited by Kristen Lubben, 330-341. Göttingen: Steidl, 2008.

Edwards, Elizabeth. "Objects of Affect: Photography beyond the Image." Annual Review of Anthropology 41 (2012): 221-234.

Edwards, Elizabeth. "Photography and the Material Performance of the Past." History and Theory 48, no. 4 (2009): 130-150.

Feinstein, Hermine. "Meaning and Visual Metaphor." Studies in Art Education 23, no. 2 (1982): 45-55.

Forsell, Håkan. “Die großstädtische Kindheit.” In Kindheiten in der Moderne: Eine Geschichte der Sorge, edited by Meike Sophia Baader, Florian Eßer, and Wolfgang Schröer, 191-225. Frankfurt: Campus Verlag, 2014.

Giese, Fritz. Körperseele: Gedanken über persönliche Gestaltung. Munich: Delphin-Verlag, 1927.

Hariman, Robert, and John Louis Lucaites. The Public Image: Photography and Civic Spectatorship. Chicago: University of Chicago Press, 2016.

Harth-Peter, Waltraud. "Schnee vom vergangenen Jahrhundert? Zur Aktualität der Reformpädagogik heute." In Schnee vom vergangenen Jahrhundert: Neue Aspekte der Reformpädagogik, edited by Winfried Böhm, Waltraud Harth-Peter, Karel Rýdl, Gabriele Weigand, and Michael Winkler, 11-27. Würzburg: Ergon, 1994.

Herman, Frederik. "Das harmonische Leben im industriellen Kosmos: Darstellungen zukünftiger Arbeiter in der ersten Hälfte des 20. Jahrhunderts in Luxemburg." In Pädagogisierung des "guten Lebens": Bildungshistorische Perspektiven auf Ambitionen und Dynamiken im 20. Jahrhundert, edited by Andrea De Vincenti, Norbert Grube, Michèle Hofmann, and Lukas Boser, 325-54. Bern: Bibliothek am Guisanplatz, 2020.

Herman, Frederik. "Forging Harmony in the Social Organism: Industry and the Power of Psychometric Techniques." History of Education 43, no. 5 (2014): 592-614.

Herman, Frederik, and Ira Plein. "Envisioning the Industrial Present: Pathways of Cultural Learning in Luxembourg (1880s-1920s).” Paedagogica Historica 53, no. 3 (2017): 268-284.

Herman, Frederik, and Karin Priem. "Images of Industrial Life and Vocational Training: Scouting as a Liminal Space for Educating a Workers' Elite in 1920s Luxembourg." History of Education 49, no. 4 (2020): 553-570, DOI:10.1080/0046760X.2019.1701098.

Herman, Frederik, and Karin Priem. "The Eye of the Machine: Labor Sciences and the Mechanical Registration of the Human Body." In Priem and Herman, Fabricating Modern Societies, 138-166.

Herman, Frederik, Karin Priem, and Geert Thyssen. "Body_Machine? Encounters of the Human and the Mechanical in Education, Industry and Science." History of Education 46, no. 1 (2017):

$108-127$. 
IEM. Programme publié à la clôture de l'année scolaire 1916-1917/Programm herausgegeben am Schlusse des Schuljahres 1916-1917. Luxembourg: Victor Bück, 1917.

IEM. Stenographischer Bericht der Versammlung vom Dienstag den 17. Juni 1913. Dommeldingen: Buchdruckerei Albert Nicolay, 1913.

Kahane, Reuven. The Origins of Postmodern Youth: Informal Youth Movements in a Comparative Perspective. Berlin: De Gruyter, 1997.

Klein, Alexandre. “'Lire le corps pour percer l'âme': Outils et appareils à l'aube de la psychologie scientifique à Nancy." In Corps et machines à l'âge industriel, edited by Laurence Guignard, Pascal Raggi, and Etienne Thévenin, 41-54. Rennes: Presses Universitaires de Rennes, 2011.

Luks, Timo. "Kanalisierte Dynamik, angeordnete Körper: Bewegungsmetaphern, Gesellschaftsordnung und der Industriebetrieb (1920-1960)." In Kontrollierte Arbeit Disziplinierte Körper? Zur Sozial- und Kulturgeschichte der Industriearbeit im 19. und 20. Jahrhundert, edited by Lars Bluma and Karsten Uhl, 251-281. Bielefeld: Transcript, 2012. MacDonald, Sharon. Memorylands: Heritage and Identity in Europe Today. Abingdon: Routledge, 2013.

Marchand, Roland. Creating the Corporate Soul: The Rise of Public Relations and Corporate Imagery in American Big Business. Berkeley: University of California Press, 1999.

Meyer-Drawe, Käte. Menschen im Spiegel ihrer Maschinen. Munich: Fink, 1996.

Nash, Paul, Andreas M. Kazamias, and Henry J. Perkinson, eds. The Educated Man: Studies in the History of Educational Thought. New York: Wiley, 1965.

Nyberg, Paul. "The Communal Man - Marx." In Nash, Kazamias, and Perkinson The Educated Man, 277-303.

Nye, David E. Image Worlds: Corporate Identities at General Electric. Cambridge, MA: The MIT Press, 1985.

Paterson, Mark. The Senses of Touch: Haptics, Affects and Technologies. Chichester: John Wiley \& Sons, 2012.

Plein, Ira. "Machines, Masses, and Metaphors: The Visual Making of Industrial Work(ers) in Interwar Luxembourg." In Priem and Frederik Herman, Fabricating Modern Societies, 35-57.

Pomfret, David M. Young People and the European City: Age Relations in Nottingham and SaintEtienne, 1890-1940. Aldershot: Ashgate, 2004.

Priem, Karin, and Frederik Herman, eds. Fabricating Modern Societies: Education, Bodies, and Minds in the Age of Steel. Leiden: Brill, 2019.

Priem, Karin, and Frederik Herman. "Introduction." In Priem and Herman, Fabricating Modern Societies, 1-32.

Priem, Karin and Frederik Herman. “'Sensuous Geographies' in the 'Age of Steel': Educating Future Workers' Bodies in Time and Space (1900-1940).” In Priem and Herman, Fabricating Modern Societies, 111-137.

Rabinbach, Anson. The Human Motor: Energy, Fatigue and the Origins of Modernity. Berkeley: University of California Press, 1992.

Robert, Aloyse. "La méthode psycho-physiologique du travail et l'orientation professionnelle." In Institut Emile Metz Dommeldange: Programm herausgegeben am Schlusse des Schuljahres 1919-1920, edited by IEM, 53-71. Luxembourg: Imprimerie Joseph Beffort, 1920.

Robert, Aloyse. “L'apprentissage industriel et l'enseignement professionnel." In Institut Emile Metz Dommeldange: Programm herausgegeben am Schlusse des Schuljahres 1918-1919, edited by IEM, 47-55. Luxembourg: Imprimerie Universelle Linden \& Hansen, 1919.

Schmid, Pia. "Die bürgerliche Kindheit." In Kindheiten in der Moderne: Eine Geschichte der Sorge, edited by Meike S. Baader, Florian Eßer, and Wolfgang Schröer, 42-71. Frankfurt: Campus Verlag, 2014.

Sennett, Richard. The Craftsman. London: Allen Lane, 2008. 
Stremmel, Ralf. "Mythen schmieden? Fotografien von Jugend in der Montanindustrie, 1949-1973." In Jugend im Fokus von Film und Fotografie, edited by Barbara Stambolis and Markus Köster, 81-113. Göttingen: V\&R Unipress, 2016.

Tenfelde, Klaus S., ed. Bilder von Krupp. Fotographie und Geschichte im Industriezeitalter. Munich: C. H. Beck, 2000.

Thommes, Jean-Pierre. "Die soziale Bedeutung der physischen Erziehung." In L'Institut Emile Metz 1914-1954, edited by Institut Emile Metz, 125-134. Luxembourg: Imprimerie Bourg-Bourger, 1954.

Thyssen, Geert, and Frederik Herman. "Re-turning Matters of Body_Mind: Articulations of IIl-/ Health and Energy/Fatigue Gathered through Vocational and Health Education." History of Education 48, no. 4 (2019): 496-515.

Thyssen, Geert, and Klaus Dittrich. "Water and Dust: Recovering Washed-Out Pasts of Industry in Luxembourg." In Education across Europe: A Visual Conversation, edited by Catherine Burke, Ian Grosvenor, Béatrice Haenggeli-Jenni, Helena Ribeiro de Castro, Elena Tabacchi, Geert Thyssen, and Pieter Verstraete, 63-66. N. p.: Network 17, Histories of Education, EERA, 2014.

Türk, Klaus. "Arbeit in der bildenden Kunst.” In Anthropologie der Arbeit, edited by Ulrich Bröckling and Eva Horn, 35-77. Tübingen: Gunter Narr Verlag, 2002.

Türk, Klaus. Bilder der Arbeit: Eine ikonografische Anthologie. Wiesbaden: VS Verlag für Sozialwissenschaften, 2000.

Tumblety, Joan. Remaking the Male Body: Masculinity and the Uses of Physical Culture in Interwar and Vichy France. Oxford: Oxford University Press, 2012.

Turner, Victor. "Liminalität und Communitas." In Ritualtheorien: Ein einführendes Handbuch, edited by Andréa Belliger and David J. Krieger, 251-264. Opladen: Westdeutscher Verlag, 1998.

Uhl, Karsten, and Lars Bluma. "Arbeit - Körper - Rationalisierung: Neue Perspektiven auf den historischen Wandel industrieller Arbeitsplätze." In Kontrollierte Arbeit - Disziplinierte Körper? Zur Sozial- und Kulturgeschichte der Industriearbeit im 19. und 20. Jahrhundert, edited by Lars Bluma and Karsten Uhl, 9-31. Bielefeld: Transcript, 2012.

Vieser, Michaela. Das Zeitalter der Maschinen: Von der Industrialisierung des Lebens. Berlin: Braus, 2014.

Wahle, Manfred. "Every Picture Tells a Story: Historical Research on Vocational Education and Training." In History of Vocational Education and Training in Europe: Cases, Concepts and Challenges, edited by Esther Berner and Philipp Gonon, 207-228. Bern: Peter Lang Publishing, 2017.

Walther, Peter. Lewis W. Hine: America at Work. Cologne: Bibliotheca Universalis, 2018.

Wengenroth, Ulrich. "Die Fotografie als Quelle der Arbeits- und Technikgeschichte." In Bilder von Krupp: Fotographie und Geschichte im Industriezeitalter, edited by Klaus S. Tenfelde, 98-104. Munich: C. H. Beck, 2000. 
